\title{
Thyroid Cancer pNX TNM Finding v6 and v7
}

National Cancer Institute

\section{Source}

National Cancer Institute. Thyroid Cancer pNX TNM Finding v6 and v7. NCI Thesaurus. Code C60872.

Thyroid cancer in which regional lymph nodes cannot be assessed. (from AJCC 6th and 7th Eds.) 